\title{
THE PERSISTENCE AND MANAGEMENT OF THISTLES IN AUSTRALIAN PASTURES
}

\author{
B.M. SINDEL \\ Co-operative Research Centre for Weed Management Systems, \\ Department of Agronomy and Soil Science, University of New England, \\ Armidale, NSW, 2351 Australia
}

\begin{abstract}
Thistles have historically been among the most troublesome weeds of temperate Australian pastures. This paper examines whether the key to effective management lies in understanding the reasons for their persistence. In addition to being protected against grazing by spines, thistles form competitive rosettes which maintain niches for future recruitment and produce numerous wind-borne seeds. Their persistence, however, is dictated mostly by long-lived seed banks at depth and the annual replenishment of seeds to surface soil. Thistle management should aim to increase the level of control by combining the suppressive effects of competitive pastures with techniques which cause high seed loss.
\end{abstract}

Keywords: thistles, weeds, persistence, control, pastures

\section{INTRODUCTION}

Thistles have a long history of being among the most widespread and troublesome weeds of temperate Australian pastures. Silybum marianum was one of the first weeds to be declared noxious under Australian legislation in 1851 (Michael 1970) and yet, despite concerted efforts to control this and other closely related species over the last 150 years or so, thistles remain a major problem for graziers in high-rainfall (approximately 500-900 mm annual average) temperate pastures. For example, in a recent survey of graziers on the Northern Tablelands of New South Wales, six of the ten most troublesome weeds were thistles and by far the weed of most concern to graziers was Carthamus lanatus (saffron thistle) (Sindel 1996).

In recognition of the importance of thistles in Australian pastures, they have recently been targeted as key weeds for research in the new Co-operative Research Centre for Weed Management Systems, initiated by the Australian Government in 1995 to coordinate research and enhance collaboration between groups working on weed management across southern Australia. Why have thistles persisted in this way? Does the key to devising effective management systems lie in understanding the reasons for their persistence?

A recent review of the literature on thistles in Australia (Sindel 1991) highlighted increases and changes in thistle dominance (particularly from S. marianum, Onopordum spp. and Carduus spp. to C. lanatus) due to differences in thistle ecology and changes in pasture management practices. This paper aims to review the unique characteristics of thistles in Australian pastures, the reasons for their success over the long term (or for the failure to bring them under control) and, as a result, identify what strategies may be best for control.

\section{UNIQUE CHARACTERISTICS OF THISTLES}

There is perhaps no other group of plants in Australia or the world which better epitomise weeds than the thistles. The leaves, stems and capitula typically have sharp spines which not only give the plants a vicious appearance, but also render them unpalatable to most classes of livestock, goats being an exception (Holst and Allan 1996). Because of this fact, they will often grow above the pasture canopy and dominate the grazing landscape throughout much of the year. Other unpalatable broadleaf weeds are

Proc. 50th N.Z. Plant Protection Conf. 1997: 453-456 
rarely as injurious as thistles and so it is perhaps not surprising then that graziers often regard thistles as their most important weed species (Sindel 1996), despite being relatively easily controlled in any one season using phenoxy-based herbicides. On the other hand, annual and perennial grass weeds may be utilised by livestock to a limited extent and are not easily distinguished in a pasture sward, but are much more difficult to kill using selective herbicides (Campbell 1997).

The principal thistles of pastures in Australia are from the tribe Cardueae in the family Asteraceae. They are Carduus nutans, C. pycnocephalus, C. tenuiflorus, Carthamus lanatus, Cirsium vulgare, Onopordum acanthium, O. illyricum and Silybum marianum.

\section{REASONS FOR SUCCESS}

All of these Cardueae thistles combine both the ecological characteristics of an effective invader and a strong competitor to establish in grassland communities. They exploit gaps in pastures following heavy grazing or other forms of disturbance, e.g. disease and insect attack, and occur over a wide range of soil types (Sheppard 1996). In addition to their defence against grazing, thistles generally form prostrate rosettes which block light to nearby competitors and suppress their germination and growth. Silybum marianum rosettes can be as large as $1 \mathrm{~m}$ in diameter and, under ideal conditions, the height of plants may reach $2-3 \mathrm{~m}$. Even when plants die, they usually remain standing for a long period of time and, by keeping the area bare of other vegetation, can maintain a niche for the recruitment of the next generation of thistle seedlings. These biological characteristics favour the growth of thistles and their dominance within a grazed pasture in and between seasons.

All of the thistles under question are monocarpic annuals and biennials and rely on seed production for continued infestation of an area (Table 1). Large numbers of mobile wind-borne seeds are produced but their mobility depends on seed weight, pappus and type of ground cover. While the viability of seeds deposited at or near the soil surface declines rapidly, seeds below 4-5 cm may remain viable for many years (Sindel 1991). Hence, the persistence of thistles in the long-term is probably dictated by these relatively small and long-lived seed banks at depth (Table 1). For example, Allan and Holst (1996) demonstrated the ease with which an infestation of Onopordum illyricum was able to flare again after 6 years of control during which time no seeds were allowed back into the soil seed bank. Another equally important factor in the persistence of thistle populations could be the survival of enough plants every year to maintain surface-soil seed banks, particularly for small-seeded species such as Carduus nutans (Table 1) which are unlikely to emerge from below $4 \mathrm{~cm}$ in the soil (Popay and Thompson 1979).

TABLE 1: Seed and life cycle characteristics of the major Cardueae thistles in Australia.

\begin{tabular}{llcccc}
\hline Thistle & Lifecycle $^{1}$ & $\begin{array}{c}\text { Seed } \\
\text { wt }(\mathrm{mg})^{1}\end{array}$ & $\begin{array}{c}\text { Germination } \\
\text { period }^{2}\end{array}$ & $\begin{array}{c}\text { Seed } \\
\text { longevity }\end{array}$ & $\begin{array}{c}\text { Intra-sp. } \\
\text { variation }\end{array}$ \\
\hline Carduus nutans & Biennial & 3.5 & $\mathrm{~A}, \mathrm{~W}, \mathrm{Sp}, \mathrm{Su}$ & $9 \mathrm{yrs}$ & $* *$ \\
Carduus pycnocephalus & Winter annual & 5 & $\mathrm{~A}$ & $10 \mathrm{yrs}$ & $*$ \\
Carduus tenuiflorus & Winter annual & 3 & $\mathrm{~A}$ & $10 \mathrm{yrs}$ & $*$ \\
Carthamus lanatus & Winter annual & 26 & $\mathrm{~A}, \mathrm{~W}$ & $5-6 \mathrm{yrs}$ & $* * *$ \\
Cirsium vulgare & Biennial & 4 & A,W,Sp,Su & $3-9 \mathrm{yrs}$ & $?$ \\
Onopordum acanthium & Biennial & 11 & A,W,Sp,Su & $>6 \mathrm{yrs}$ & $* * *$ \\
Onopordum illyricum & Biennial & 15 & A,W,Sp,Su & $>6 \mathrm{yrs}$ & $* * *$ \\
Silybum marianum & Winter annual & 22 & A,Sp & $9 \mathrm{yrs}$ & - \\
\hline
\end{tabular}

${ }^{1}$ After Michael (1968)

${ }^{2}$ A = Autumn; W = Winter; Sp = Spring; Su = Summer (after Peirce 1996)

${ }^{3}$ Indicative longevity figures from the literature, for seeds buried at depth

${ }^{4}$ Number of ' $*$ ' $=$ degree to which attribute is present in the species (after Groves 1996)

Despite their taxonomic and morphological similarities and the common problems 
that they cause for agriculture, thistles cannot be regarded as a homogeneous group. Thistles are ecologically diverse, both between and within species, and this has been one of the reasons for their success as a group (Table 1). In particular, Carthamus lanatus is a typical weed of regularly disturbed areas with coarse dry topsoil, but with good reserves of moisture in the deeper subsoil. On the other hand, most of the other thistles are dominant on soils rich in phosphate and nitrogen, and possibly regularly cultivated and/or irrigated areas (Doing 1972). Hence, unlike most of the other thistles, C. lanatus is a major weed of cereal crops as well as pastures and can fill niches left by the control of other thistles. This species too has been shown to contain distinct biotypes in Western Australia (Peirce 1990). Such ecological diversity needs to be accounted for in biological control, where insect and disease agents can have narrow intra-specific host ranges, as well as in herbicidal control (Peirce 1996). While Australia is the only country in the world in which C. lanatus poses a major weed problem, the species has purportedly been introduced to countries like New Zealand in contaminated grain from Australia (Parsons and Cuthbertson 1992).

\section{STRATEGIES FOR CONTROL}

Sheppard (1996) argues that most thistles are relatively short-lived, reproduce entirely from seed and persist by way of viable seeds on and below the soil surface. Therefore, causing high seed loss should be the dominant control strategy. All control tactics that either weaken thistle plants or reduce plant number at the beginning of the season, e.g. pasture competition and herbicide application, are likely to reduce seasonal seed production. Control measures are also needed towards the end of the season which directly result in loss of viable seeds from plants which survive earlier attempts at control, e.g. seed- or receptacle-feeding insects, spray-topping, grazing with goats, or slashing. Currently, there is no effective way of removing or killing thistle seeds in the seed bank under pasture, although that research goal may well be a desirable one.

It needs to be realised that weed control per se is not the desired outcome of thistle management but rather the maintenance of a productive pasture that adequately feeds the livestock which graze it. This assumes that weeds are not merely a cause of pasture degradation but perhaps more importantly a symptom of pasture decline. It is imperative, therefore, that any thistle control program must be based on the establishment and maintenance of a dense and vigorous perennial pasture, particularly during periods of peak germination and establishment. Grazing in heavily infested paddocks should be managed to provide lighter stocking rates at these times in order to increase competition and suppress thistle establishment and seedling survival (Sindel 1991). Information on the germination times of thistles at a regional level (cf.Table 1) is critical to this approach.

Cook et al. (1978) showed that pastures throughout southern Australia could potentially benefit in terms of production and weed suppression from periods of spelling or lax grazing and the application of adequate fertilisers. Hence, to achieve sustainable pasture production, land managers will need to focus on improving pasture quality and persistence. Effective weed control will be both a component of good pasture management as well as an outcome of the process.

Integrated weed management which combines all appropriate weed control tactics (biological, chemical and cultural) has been highlighted as the next stage in modern weed management, especially as a means of overcoming the problem of herbicide resistance. Herbicides are not used intensively in Australian pastures but, as found in New Zealand (Harrington 1990), herbicide resistance in thistles remains a threat. An added benefit of an integrated approach to thistle management is the potential to improve the overall effectiveness of control. Integrating the potentially antagonistic techniques of grazing, biological control, herbicides and fertiliser usage into strategies for thistle management has been identified as a high priority for future research in Australia (Brieseet al. 1996).

ACKNOWLEDGEMENTS

I am grateful to Dr Jim Scott for his comments on a draft of this paper. 
Allan, C.J. and Holst, P.J., 1996. Longevity of soil based seeds of Onopordum illyricum. Pl. Protect. Quart. 11: 242.

Briese, D.T., Woodburn, T.L., Kemp, D. and Corey, S., 1996. Workshop outcomes - a blueprint for research into the management of thistles. Pl. Protect. Quart. 11: 290292.

Campbell, M., 1997. Pasture weeds. Pp 254-268In: Pasture Production and Management, J.V. Lovett and J.M. Scott (Eds). Inkata Press, Melbourne, Australia.

Cook, S.J., Blair, G.J. and Lazenby, A., 1978. Pasture degeneration. II. The importance of superphosphate, nitrogen and grazing management. Aust. J. Agric. Res. 29: 1929.

Doing, H., 1972. Botanical composition of pasture and weed communities in the Southern Tablelands region, south eastern Australia. CSIRO Aust. Div. Plant Indust. Technical Paper. 30: 1-40.

Groves, R.H., 1996. The biology and control of certain Compositae weeds from Mediterranean-type environments. Pp 321-331 In: Compositae: Biology and Utilization, P.D.S. Caligari and D.J.N. Hind (Eds). Proceedings of the International Compositae Conference, Kew, 1994. (D.J.N. Hind, Editor-in-Chief), Vol. 2. Royal Botanic Gardens, Kew, England.

Harrington, K.C., 1990. Spraying history and fitness of nodding thistle, Carduus nutans, populations resistant to MCPA and 2,4-D. Proc. 9th Aust. Weeds Conf.: 201-204.

Holst, P.J. and Allan, C.J., 1996. Targeted grazing of thistles using sheep and goats. Pl. Protect. Quart. 11: 271-273.

Michael,P.W., 1968. Thistles in south-eastern Australia-some ecological and economic considerations. Proc. 1st Victorian Weeds Conf:: 4-12 to 4-16.

Michael, P.W., 1970. Biology and ecology of thistles. Proc. Weed Soc. N.S.W. 3: 3-6.

Parsons, W.T. and Cuthbertson, E.G., 1992. Noxious Weeds of Australia. Inkata Press, Melbourne, Australia.

Peirce, J.R., 1990. Morphological and phenological variation in three populations of saffron thistleCarthamus lanatus L. from Western Australia.Aust. J. Agric. Res. 41: 1193-1201.

Peirce, J., 1996. The relevance of variation in thistles to herbicidal control. Pl. Protect. Quart. 11: 277-279.

Popay, A.I. and Thompson, A., 1979. Some aspects of the biology of Carduus nutans in New Zealand pastures. Proc. 7th Asian-Pacific Weed Sci. Soc. Conf.: 343-346.

Sheppard, A., 1996. Weeds in the Cardueae: biological control and patterns of herbivory. Pp 291-306 In: Compositae: Biology and Utilization, P.D.S. Caligari and D.J.N. Hind (Eds). Proceedings of the International Compositae Conference, Kew, 1994. (D.J.N. Hind, Editor-in-Chief), Vol. 2. Royal Botanic Gardens, Kew, England.

Sindel, B.M., 1991. A review of the ecology and control of thistles in Australia. Weed Res. 31: 189-201.

Sindel, B.M., 1996. Grazier attitudes to weeds, research and education in northern New South Wales. Proc. 11th Aust. Weeds Conf:: 247-250. 